\title{
The Discourse on the Relationship of Power between the State and the People in Indonesian Indie Band Song
}

\author{
Bahiroh Adilah \\ Communication Department, Universitas Airlangga,Universitas Airlangga \\ Jalan Dharmawangsa Dalam No. 4-6, Indonesia. \\ Email: bahirohadilah66@gmail.com
}

\begin{abstract}
A B S T R A C T
This research focuses on analyzing the discourse of the power relation between the state and the people in Indonesia in the lyrics of the songs "Kami Belum Tentu" and "Padi Milik Rakyat" by Feast (group band). Intolerance became Indonesia main concern in 2018 especially Surabaya's church bombing, which then elaborated on other issues related to the socio- economic and political phenomena in Indonesia. The two songs were chosen because they adequately describe the socio-economic and political conditions in Indonesia and related to various sectors of government.This study uses Normal Fairclough's critical discourse analysis method to read the discourse on power relations between the state and the people which is articulated in the lyrics of the two songs. The results of this study conclude that the discourse on power relations with the form of Governmentality is spread in various areas of government, including in the leadership of a democratic country, the education system in Indonesia, the law constitution of UU ITE, towards farm workers through Reforma Agraria, and also in the management of tax money in Indonesia. The people will always be in a repressive state power system and the state uses its political power to carry out hegemonic submissions that are detrimental to the people structurally and economically through the ISA (Ideological State Apparatus) and RSA (Repressive State Apparatus) which critized in Indonesian indie song lyric.
\end{abstract}

Keywords: critical discourse analysis; power relation; governmentality; Ideological State Apparatus; Repressive State Apparatus

\section{A B S T R A C T}

Penelitian ini berfokus pada analisis wacana relasi kekuasaan antara negara dan masyarakat di Indonesia dalam lirik lagu "Kami Belum Tentu" dan "Padi Milik Rakyat" karya Feast. Berawal dari masalah intoleransi di tahun 2018, pengeboman gereja di Surabaya, yang kemudian mengelaborasi isu-isu lain terkait dengan fenomena sosial ekonomi dan politik di Indonesia. Kedua lagu tersebut dipilih karena cukup menggambarkan kondisi sosial ekonomi dan politik di Indonesia dan terkait dengan berbagai sektor pemerintahan.Penelitian ini menggunakan metode analisis wacana kritis Normal Fairclough untuk membaca wacana relasi kekuasaan antara negara dan rakyat yang ada. diartikulasikan dalam lirik kedua lagu tersebut. Hasil penelitian ini menyimpulkan bahwa wacana tentang relasi kekuasaan dengan bentuk governmentality tersebar di berbagai bidang pemerintahan, antara lain dalam kepemimpinan negara demokrasi, sistem pendidikan di Indonesia, undang-undang konstitusi UU ITE, terhadap buruh tani. melalui Reforma Agraria, dan juga dalam pengelolaan uang pajak di Indonesia. Rakyat akan selalu berada dalam sistem kekuasaan negara yang represif dan negara menggunakan kekuatan politiknya untuk melakukan pengajuan hegemoni yang merugikan rakyat secara struktural dan ekonomi melalui ISA (Ideological State Apparatus) dan RSA (Repressive State Apparatus) yang kemudian dikritisi dalam lirik lagu indie indonesia.

Keywords: critical discourse analysis; relasi kuasa; governmentality; Ideological State Apparatus; Repressive State Apparatus 


\section{A. INTRODUCTION}

This research analyzes the discourse of power relation between the state and the people in two songs from the Feast Band, namely "Kami Belum Tentu" and "Padi Milik Rakyat" in mini album Beberapa Orang Memaafkan. The album itself is a responsive work on the bomb incident in Surabaya in May 2018. This incident triggers for the elaboration of song material which ultimately helped raise other social criticisms of social phenomena in Indonesia.

Song creation is not just for the entertainment function, but there are also ideas to be conveyed. Through language, communicators can convey their ideas to the communicant. The words spoken, the symbols given, and the intonation of speech are not merely personal expressions or ways of communicating, but are used deliberately for a specific purpose (Rahardjo, 2011). The song has lyrical elements which are important part of the song. The lyrics contain certain words that is deliberately conveyed by the lyricist. Lyric itself function as a universal and effective medium in conveying ideological ideas for specific purposes, for example social criticism, criticism of the state, criticism of social and political phenomena, and others.

Language can be used as a discourse formation in a song. Therefore, the use of language in song lyrics cannot be interpreted as it is. There is a language structure that is deliberately used to convey the opinion of the lyricist. The choice of words was deliberately formed to build a particular discourse with a certain social context as well. Language embodies and articulates the experience of social struggle, transition, and contest, and consequently the linguistic sign is seen as deeply ideological (Blommaert, 2006). So that the researcher sees the song lyrics as a language use text that will be analyzed as a certain discourse to convey ideological ideas in the song.

There are many Indonesian musicians who are famous for their songs that raise their concern about the socio-political conditions in Indonesia. An old Indonesian musician, Iwan Fals, is famous for his works on political criticism and social justice in Indonesia at that time. The lyrics created by Iwan Fals are very thick with criticisms of the state. According to research from Prastiwi (2017), the musical works created by Iwan Fals mostly convey ideas about the social and political conditions that occur, each of his works representing his every idea and criticism of problems that occur in society(Prastiwi, 2017).

The development of the music industry in Indonesia gave rise to other musicians who also voiced socio-political criticism through musical works. Five musicians who were chosen by CNN Indonesia in 2016 who also voiced socio-political criticism, including Slank, Efek Rumah Kaca, Navicula, Nosstress, and Supermaan Is Dead (Putra, 2016).

This phenomenon both explains and proves that songs, especially in the lyrical element, can be a medium for socio-political criticism that is easily accepted by the wider community. Song lyrics are also a means of forming certain discourses in the creation of a musical work which is increasingly loved by Indonesian musicians as a form of concern for the current sociopolitical conditions of Indonesia.

The social and political criticism that was brought in the song became quite an interesting discourse for some musicians in song creation. After the fall of the New Order, people increasingly started to voice their ideas in various forms, one of which was in the art of music. Some people are increasingly sensitive to the socio-political phenomena that occur in Indonesia, which ultimately makes this phenomenon a discourse to be conveyed to a wider public space. 
The discourse itself, according to Hawthorn, is linguistic communication which is involved as an exchange between speaker and listener, as a personal activity whose form is determined by its social goals (Badara, 2012). This definition explains that messages that are formed to be communicated in the context of certain social goals form a particular discourse. Discourse can be interpreted based on social contexts related to certain social goals in the discourse.

Therefore, based on Rachmah Ida's book (2018), discourse analysis will deconstruct the interpretation and "reading" of the researcher on a problem or socio-political texts(Ida, 2018). The assumption is that each text has been conditioned/constructed and is embedded in the discourse or discourse that has been formed. If we talk about social and political criticism in social phenomena, it is closely related to the power relations between the authorities and subordinate groups. Looking from the ideological perspective according to Marx described by Strinati (2010), the ideas of the ruling class are increasingly emerging and dominating the thought of subordinate groups, and therefore ideological domination serves to maintain a system of class inequality(Strinati, 2010). These ideas underlie the emergence of socio-political phenomena that give rise to a certain conflict in the relationship between the two classes.

Referring to Althusser's (2014) understanding of ideology, the ideological domination referred to above is the true essence of ideology, which tends to form manipulative discourse because the real reality is hidden behind the discourse(Althusser, 2014). In connection with the concept of power, Althuser also states that ideology can form individuals based on the ideology of a particular community group, so ideology essentially serves power and maintains that power. The essence of this ideology will certainly form a relationship in the existing power structure, for example, in the power system in a country. Through these relations, there arises submission to the rules through various apparatuses in the superstructure region. The state is considered as a "machine of repression" to ensure the domination of the ruling class over the people (Althusser, 2014).

The domination of an ideology, especially the ruling class, is also closely related to Gramsci's concept of hegemony. Strinati (2010) explains that hegemony is something that comes from class and social struggles which in turn functions to shape and influence(Strinati, 2010). The domination of ideology or the concept of hegemony in this context relates to power relations in an institution, which refers to an institution called the state. This is what Foucault (1982) calls the "Governmentality" mode of power, which is an extension of the power relations model at the state level, so that it will talk about the territorial issues of a country in an effort to control and control resources and population for the benefit of the state (Mudhoffir, 2011). It can be said that governmentality is a form of power relations that will center on the interests of the state and will always be under state control. According to Foucault (1982) hegemonic submission is a mechanism for normalizing the dominant relation to the dominated subject, so that the subject does not have room to maneuver or make choices in acting (Mudhoffir, 2011)

In relation to the concept of governmentality, Strinati (2010) also explains that in this perspective, popular culture can be interpreted in terms of the struggle against hegemony (governmentality) which is carried out in civil society institutions(Strinati, 2010). This explains that popular culture, in this context, music / song works of art can be used as a form of social criticism from the perspective of civil society against rulers who practice hegemony or governmentality according to Foucault's terms.

Feast is a band that has had interest from their formation phasein social criticism within 
their songs. On September 21, 2018, Feast released a mini album entitledBeberapa Orang Memaafkan (Some People Forgive) with the background of Earth. The mini album is purely a responsive work on an event in Indonesia, namely the Surabaya bombing incident in May 2018. This issue became a trigger for Baskara Putra as a lyricist to elaborate on the song material so that 6 songs with different phenomena set in Indonesia were created.

For this research i chose two songs from the mini album Beberapa Orang Memaafkan to be used as research objects, including "Kami Belum Tentu" and "Padi Milik Rakyat". The reason $\mathrm{i}$ chose the two songs to be the object of research is because the two songs have the similar and strong discourse thread, namely the power relation between the state and the people towards the state in the lyrics of the song.

\section{B. METHODS}

The research method used is Norman Fairclough's Critical Discourse Analysis. This critical discourse analysis model focuses on language as a form of power practice in conveying ideological values. This analysis will be derived into three dimensions, namely the dimensions of text, discourse practice, and socio-cultural context, then intertextual will be carried out from the three dimensions.

As the focus and limitation of the analysis of this discussion, I determined what are the indicators of power relations and how governmentality practices according to Foucault (1991), including the existence of procedures and rules that cause hegemonic submission, walking in unequal relationships, operate on thoughts (ideologies) that influence behavior, unbalanced dependency pattern, power is also synonymous with one-sided gain from a particular group (Martin, 1995), the ruler has the ability to play an important social role in society, especially in the unequal abundance of material in a community group. (Martin, 1995), domination is a part of power relations and is stable, hierarchical, permanent, and non-exchangeable. According to Foucault (1988) domination refers to an asymmetrical form of relationship in which one of the dominated parties has little room to act because of their limited rights of freedom (Mudhoffir, 2011).

This research is crucial because there is a discourse behind the text of the lyrics regarding social phenomena that are relevant to the context and socio-political conditions in Indonesia. The research method used is a discourse analysis method with a qualitative

approach. Faircloigh method was chosen because it focus on the reading and interpretation of the texts in the song lyrics which are articulated as a discourse, relating it to the existing sociocultural context or conditions,so that the sub-chapters in the discussion can be categorized based on the relations and government sectors which become the discourse on the substance of the song lyrics based on the indicators previously mentioned.

\section{RESULTS AND DISCUSSION}

In this section, the interpretation of the lyrical text narrates the bad behavior of political elites, the capability of state leaders to represent the voice of the people, and how these political elites develop certain discourses to deceive their people. The first stanza expresses the deterioration of political conditions in Indonesia and the nickname 'chameleon' attached to the political elite. In the findings of researchers on several news stories, the label 'chameleon' was assigned to several political parties and political elites, for example the Democratic Party, PAN, 
Sandiaga Uno, Prabowo, SBY, and others. In the news, the term "chameleon" is articulated as a party who easily positions himself as part of various ideologies based on what interests are behind him.

By positioning oneself as part of the ideology of various groups of society, the interest in getting the attention and support of these community groups is achieved. The articulation of the term 'chameleon' which can be associated with the term populism in politics. One of the characteristics of populism appears, namely rally the people in the name of their political struggle while ordaining an elite in a completely negative and arbitrary image (Salahudin, 2019).

The next two stanzas (chorus) express a call for doubt about the capability of the leadership in Indonesia in representing the voice of the people and how the country's leaders or elites use their power. More specifically, this stanza raises the phenomenon related to manipulating the track records of the elites as if they were clean again and could regain the people's trust. The ruler has the ability to play an important social role in society(Martin, 1995). It is the same with leaders who have an important social role in society, therefore how a leader plays that social role determines social life and the condition of his community. Moreover, Indonesia is a democratic country that should have a style to uphold a democratic system of representation. The question is then asked whether the leaders in Indonesia are sufficiently running the system of representation.

The researcher took some news that was a reflection of the conditions that occurred in Indonesia, including news stating that the aspirations of the people's voice were ignored by the state, news that stated various controversies in the track record of the ministers appointed by Jokowi. Starting from the Minister of Health Terawan having problems with the medical code of ethics, Minister of Home Affairs Tito and Menpora Zainudin were caught in a corruption case (Nathaniel, 2019). Not to mention the Minister of Defense Prabowo, who was closely related to the case of disappearing activists in 1998 and Vice President Ma'ruf Amin with various controversial MUI fatwas (Islamic laws).

Referring to this news, I found there were other interests running behind the election of Jokowi's ministers and vice president. When talking about the ideal leader in a democratic country, the names chosen and even Jokowi himself are still far from this ideal concept. The pattern of forming a new discourse which is always applied to almost political situations in Indonesia in order to perpetuate the position of the elite and society will still be required to obey and submit. In the context of leadership in Indonesia, there is the normalization of chameleon politics or populism, where state elites position themselves as part of all groups and ideologies so as to make the people the main interest, even though only as a political commodity for the benefit of mobilizing votes during the campaign.

The state does not play its role as a democracy to represent the voice of the people because of the ongoing governmentality. Governmentality works through the discourse of freedom in a democratic country to regulate and direct the people as the state wishes. According to Foucault's (1991) definition of governmentality, power relations occur because of an unbalanced dependency pattern(Foucault, 1991). Like a country that does not prioritize the voice and interests of the people in running a system of government. The state continuously produces discourse as an authoritative form of knowledge to control the state for its own political interests. This imbalance causes the power relationship between the state and the 
people to create hegemonic submission, as one of the characteristics of governmentality that is running in Indonesia.

\section{Power Relations Discourse: Governmentality in the Indonesian Education System}

In this section, the researcher looks at the interpretation of the lyric text on how the lyrics of the song "Kami Belum Tentu" articulate the depiction of the education system in Indonesia through concrete cases that occur in Indonesia. The researcher will describe how the discourse of power relations between the state and its people, in this context, the state and community elites who are in the circle of the education system.

Based on the interpretation of the lyric text, the researcher took several related news that described the situation in Indonesia, including the increase in the education budget, including an increase in LPDP scholarships. However, this increase is in line with the increase in the unemployment rate per 2019, the low quality of education in Indonesia (an average from the World Bank), the absence of improvement in the quality of education, and the increase in cases of corruption in the education sector to reach Rp. 1.3 trillion. The relationship of this situation becomes very ironic when the education budget increases but there is no improvement in the quality both in the aspect of education and its relationship with the community. It can be said that the above incidents are detrimental to the people who should receive good and quality education.

Analysis showed that there was a misdirection of funding, so that the allocation of the education budget did not match the portion it should have. It is these errors and mismatches that make the quality of education in Indonesia still low and not in balance with the education figures above. The fact that is happening in the education sector in Indonesia is that an increase in the budget for funds is actually accompanied by an increase in the mismanagement of funds. These frauds and acts of corruption are related to elite figures who have authority over the education system in Indonesia. The poor performance of Indonesia educational institutions cannot just be explained by the proximate causes, it also reflects the way that a range of elite actors, including bureaucrats, political leaders, and business people, have often stymied efforts to improve the quality of the education system (Rosser \& Fahmi, 2018).

The researcher carried out a historical analysis, namely by putting the context of the incident backwards to find out the roots of the discourse on power politics and how the relationship between the state and its people. Robison (1986) states that the existence of power politics has its roots in the New Order era, when there was political domination by state and corporate elite figures in controlling the state and its people(Robinson, 1986). The existence of this political domination and power then creates an education system that tends to be repressive and only seeks to realize the interests of the state.

Talking about the application of power politics in the education system, the narrative is related to how Paulo Freire's criticism of the education system is running. The state regulates the education system, of course there will be control by the state on how education is distributed to the community. The state also has certain ideologies that accompany interests in the education system where there is the possibility of potential hegemony in it, so that it has an impact on the emergence of oppression. Oppression in the education system is a structural oppression that creates a process of impoverishment, both economically, politically, socioculture, and ideologically (Freire, 1985). 
The narratives above are a form of the discourse of dominant state relations and make the people the object of fulfilling interests. The power relation that runs in the above phenomenon is preceptorial power, where the relationship is woven through knowledge by means of persuasion (Imbeau, 2007). The state uses this preceptorial power through uniformity in people's thinking. When the state succeeds in making its people submissive and obedient through subtle persuasion, then the state takes the opportunity to commit fraud, namely corruption in education funds, as previously mentioned.

The relationship that occurs in the education sector is also related to the concept of the state apparatus belonging to Althusser (2014), that the state carries out hegemony through the ISA (Ideological State Apparatus), one of which is the education system through manipulative work through state ideology to fulfill people's obedience(Althusser, 2014). The education system became a means of launching power politics rooted in the New Order regime. The state perspective sees education as a spreader of state ideology for the sake of political and economic interests, such as the purpose of printing human resources to advance the country's economy, but not accompanied by a secure job guarantee. The state uses disciplinary power as a form of governmentality, where the state places the people as the fulfillment of the country's interests ideologically and economically through the Indonesian education system.

\section{Power Relations Discourse: Implementation of Governmentality through the Constitution of the ITE Law}

This section will be focusedon how the lyrics of the song "Kami Belum Tentu"articulate the depiction of the implementation of policies made by the state regarding the cyber world through concrete cases that have occurred in Indonesia. Through this stage the researcher will explain how the discourse of power relations between the state and its people, in this context are policy makers and internet users in the cyber area.

The researcher took one of the cases of site blocking by the Ministry of Communication and Information, which was the same as what was written in the lyrics of the song "We Are Not Sure". The blocking of Tumblr and Reddit sites by the Ministry of Communication and Information is not the first-time case, but through series off block and unblock. Release limitation policy then revoked the policy and then blocked the internet again. According to the news, the Ministry of Communication and Information explained that the two sites contained pornographic content and violated articles of the ITE Law. As is well known and seen in cases related to the ITE Law, the ITE Law still deals with the problem of 'rubber' articles or multiintepretive articles which are create more opportunities to be twisted and manipulated in such a way.

In addition, there was the Vimeo blocking case, where the cause of blocking the Vimeo website was allegedly due to the appearance of a video entitled "Goyang Seronok in the PKS Candidate Campaign" which showed the erotic rocking of dangdut singers at a PKS legislative candidate campaign event. Based on the researcher's findings, the Menkominfo also blocked various sites suspected of containing SARA. Nevertheless the lack of transparency from the Ministry of Communication and Information regarding which sites were blocked raises suspicion as well as a question as to why only 11 sites were informed through the official website of the Ministry of Communication and Information. In addition, this blocking step led 
to various protests from site administrators due to the absence of any notification and explanation from the Minister of Communication and Information. Especially on a site that is not included in the official list of Kominfo, suarapapua.com, it has further raised suspicions of other interests behind this step. Given the minimal coverage of Papua by the national media and the state's discriminatory treatment of Papua.

Regarding blocking measures, the Minister of Communication and Information uses Article 40 of Law Number 11 of 2008 concerning Electronic Information and Transactions (UU ITE), which in point (2) reads "The government protects the public interest from all kinds of interference as a result of misuse of Electronic Information and Electronic Transactions. disturbing public order, in accordance with the provisions of the Legislation". Then the article underwent a revision and was ratified by the DPR in 2016, which added points (2) to (2a) and (2b). This paragraph reads (2a) "The government is obliged to prevent the dissemination and use of electronic information and / or electronic documents that have contents that are prohibited in accordance with the provisions of the Regulation. Legislation ", while paragraph (2b) reads" In taking precautions, as referred to in paragraph (2a), the government has the authority to terminate access and / or order electronic system administrators to terminate access to electronic information and / or electronic documents that have loads that violate the law".

The amendment to Article 40 paragraph 2 has made the public even more repressed, with the addition of the term "obligatory" to the contents of the verse, indicating that the opportunities and freedom of the state are increasingly being opened up to carry out arbitrary blocking on sites that contain negative content and violate the law. Quoting the words of the Minister of Communication and Information, Rudiantara, who said that the importance of amending Article 40 of the ITE Law is because the government is obliged to prevent negative things (Hidayat, 2016). Meanwhile, the law does not have a clear and firm definition of what kind of negative content. The unclear definitions and benchmarks make the articles in the ITE Law as a powerful weapon for the state to legitimize various blocking actions against websites. This action is then seen as a form of rationalization of the discourse of power relations between the state and its people where power is exercised by the state so that its operation is legitimized (Foucault, 2002).

In addition, researchers took several news and related data, including the snare of the ITE Law which was widely used by state officials, the increasing number of cases of criminalization of the ITE Law, accompanied by a statement by BPS stating that Indonesia's democracy index had decreased, as well as the arrest of activists and musicians. who voiced criticism of the state through social media during the September 2019 Bill demo. The criminalization of the activist's arrest was also charged with the articles of the ITE Law. The current entanglement of the ITE Law has begun to touch the area of arresting activists, silencing the student movement, and silencing critics of the state. Repressive silencing of activists is a typical style of the New Order regime, where the state apparatus was arbitrary in treating people who wanted to voice their criticism of the state. The New Order regime has begun to re-emerge in the current government ecosystem, where the state prefers a coercive way and is considered to solve problems. In fact, the emergence and enforcement of the ITE Law was at a time when the country's democracy was developing after the New Order era. However, the longer the implementation of the ITE Law, it brought back the distinctive styles 
of the New Order regime.

Based on the description above, the researcher sees an unbalanced power relationship between the state and the people. The state uses the ITE Law as a concrete form of governmentality a la Foucault (1991), especially sovereign power to rationalize the power owned by the state so that its operations and actions are legitimized through the constitution and the validity of the law(Foucault, 1991). So that the state can regulate the actions of its people in a repressive manner to obey the power of the state. The ITE Law is a law that is used as a state political weapon to silence the public, not to protect the public.

As a result, the Indonesian state, which should have been a democratic country, has become contradicting its realization. The way the ITE Law works as a state political tool reminds us of the New Order regime where there was no democratic space for the people and the state instead used the state apparatus to act repressively against the people, resulting in repeated arrests of activists. In addition, the validity and credibility of the substance of the ITE Law are still highly doubtful and questionable. However, the state actually uses this as a form of governmentality to repress people who oppose the state to obey the state ideology by force. In this context, the state acts as the executor of political power to carry out hegemonic submission so that the people do not have room to maneuver or make choices to act (Foucault, 1988).

\section{Power Relation Discourse: Governmentality towards Farmer Workers through Agrarian Reform}

This section will discuss how the lyrics of the song "Padi Milik Rakyat" articulate the inequality conditions of the peasants who do not get what they should from the state and how the state treats the peasants. In reality, farmers in Indonesia are experiencing quite complex agrarian problems which have yet to be resolved. Starting from issues related to inequality, climate change, lack of access to technology and information, low levels of welfare, to global market issues. These various problems can be resolved if farmers achieve a high level of welfare. To achieve this prosperity, certainty of land ownership, market guarantees, and adequate access to information technology are needed, and the state should exist as the provider of these needs. But back again to the reality that is not in accordance with what it should be, the state does not act as a service provider, instead as the cause of these problems.

As previously mentioned, the majority of the total number of poor people in Indonesia (28.55 million people in September 2013) live in villages and work in the agricultural sector (Kadir, 2014). In addition, data from the Central Statistics Agency (bps.go.id) noted that the nominal wages received by farmers in 2014 ranged from IDR 43 thousand to IDR 45 thousand per month. In January-June 2019, the nominal wages of farmers have indeed increased, reaching the range of Rp. 53 thousand to $\mathrm{Rp}$. 54 thousand per month. In addition to problems related to farmer welfare, rural labor is also part of the agrarian problem, because this aspect is related to the exploitation of a mass of poor farmers in managing agricultural land (Sangadji, 2018). In this case, the state has not succeeded in becoming a service provider for farmers who are the main sector in the country's economy. Reflecting on the unsolved agrarian problems, researchers see that the role of the state has not been implemented and has become a major factor in the occurrence of these problems. For example, the Agrarian Reform program which 
is run by the state, especially in the Jokowi-JK administration.

Based on data findings, Jokowi's Agrarian Reform program has narrowed the concept to just land redistribution and land certification. Agrarian reform in its true meaning does not only include large amounts of land redistribution, but also provides infrastructure, services and a number of programs related to agrarian affairs (H57, 2020). Likewise, with resistant certification, this action does not solve the main problem experienced by farmers, namely the gap which is of course related to the level of welfare of the farmers. If you reflect on the main foothold of the Jokowi administration, the political motive for the land certification program which is being implemented on a large scale is of course to accelerate the investment agenda with a longer term.

In addition to the misappropriation of the concept of Agrarian Reform, Komnas HAM stated that most agrarian conflicts are human rights issues, this is related to the criminalization of farmers and also agrarian activists. The existence of criminalization of farmers is caused by evictions and forced expropriation of land for the purposes of expansion of land owned by corporations. In this case, the state sided with the parties when in this context, namely corporations, so that agrarian issues related to the application of the capitalist economy applied in Indonesia. Agrarian issues are indeed a familiar problem for Indonesia. The increase in agrarian conflicts during the Jokowi-JK era, one of which is due to the accumulation of conflicts in the previous period that have not been resolved, because agrarian conflicts are considered as old and latent conflicts, which then escalate their violence. In this section, the researcher will look at the discourse from the historical dimension. As previously explained, agrarian conflicts are old conflicts that have accumulated from previous conflicts, especially since the New Order.

Since the Soeharto government, investment, trade and financial liberalization policies have been gradually implemented (Sangadji, 2018), in which there is the involvement of foreign investors who can reach various sectors. This policy then plunged Indonesia into the capitalist economic system that is in effect today. This context also relates to the monopoly of land tenure during the New Order era, which later cannot be separated from the application of an extractivism economic model in Indonesia, capitalist economic development by means of extracting natural resources such as petroleum, biofuels, minerals, and agricultural foodstuff products. (Petras \& Veltmeyer, 2014). So it cannot be denied that there is the exploitation of peasant labor which continues to this day for the sake of state investment.

The existence of agrarian conflicts in Indonesia as a whole is caused by several factors. First, the dualism of law that runs in Indonesia, state law and customary law (people). Customary or people's law operates according to local social norms that run on the basis of people's awareness of what is appropriate and inappropriate, what is fair and what is unfair. Meanwhile, state law works to demand people's compliance because of the power factor of the state apparatus (Mustain, 2017). The two laws are of course mutually contradictory and tend to benefit the state because of this power factor. In the agrarian context, the state has full authority to regulate and act against the people, although it tends to be repressive.

The second factor is the existence of a third party in the relationship between the state and the people, namely corporations that lead to the entry of the capitalist economy. This also relates to the historical dimension, in which during the New Order era, Suharto launched a system of liberalizing investment in various sectors so that he began to enter the capitalist 
economy which has been running until now. This system has led to the pro-market and corporate side of the state so that the peasants are only considered as producer workers who are required to produce global market commodity products. From there, the exploitation of the peasants and the imbalance of the relationship between the state and the people led to the various conflicts described above. Starting from the imbalance of land ownership to the case of criminalization of the peasants by the state apparatus.

Especially during the Jokowi administration, which still saw the Agrarian Reform program as an economic problem only, without paying attention to issues of justice and social welfare of the peasants. Consciously, the state chose a pro-market Agrarian Reform program to maintain a capitalistic agrarian structure. Through the bureaucratization and corporatization of the state, the role of the state is systematically designed to support the interests of capital (Mustain, 2017). This system then increases agrarian conflicts in Indonesia and marginalizes peasants, especially human rights conflicts because they involve violence perpetrated by state officials. According to Scott, social inequality in rural areas occurs as a result of the expanding role of the state in the rural transformation process which tends to be carried out repressively (Mustain, 2017).

The existence of criminalization and violence by the state against the people, especially the peasants, is related to Althusser's (2014) explanation of the RSA (Repressive State Apparatus) which involves the state apparatus, specifically the police and the army, to act coercively against the peasants(Althusser, 2014). When viewed from the perspective of the state, the application of the corporatization system occurs because the state considers that state investment will stagnate if a pro-market system is not implemented. So, when the state implements the system, it cannot be denied that there will be military violence because this is a systematic objective imperative of capitalism (Sangadji, 2018). It cannot be denied that there is resistance from the people due to state policies, as mentioned by Foucault (2002), that where there is power to work, there is anti-power or resistance(Foucault, 2002).

So that in this section, the power relations that occur between the state and the people are influenced by third parties, namely corporations. The power relation runs unbalanced and equal because of the support of the state towards corporations, while the people are marginalized. The existence of governmentality in these power relations where the state has the ability to play an important social role in society, especially in the abundance of material that is not evenly distributed and the existence of partisanship (Martin, 1995). The political power to take sides has ultimately led to unresolved gaps and inequalities in the people. The state will continue to side with the corporation and the people, especially the peasants, will continue to be marginalized due to the use of this power. If the three parties can work together well without taking sides, then the management of the country will achieve prosperity. However, in reality, the role of the state is in favor of the interests of the corporation and tends to be exploitative for the people, especially the peasants.

\section{Power Relations Discourse: Implementation of Governmentality through Management of People's Tax Money}

This section discusses the lyrics of the song "Padi Milik Rakyat" which states how the tax system is implemented in Indonesia as well as various irregularities launched by the 
political elites themselves. The flow of discussion this time will begin with several cases of tax evasion and will explore how the causes and impacts on the people and also related to the affected sectors.

In this context, researchers will refer to tax irregularities by state elites which of course will not be separated from one of the largest tax evasion cases in Indonesia which involves many other officials, namely the case of an employee of the Directorate General of Taxes, Gayus Tambunan. It is an important note for Indonesia that Gayus Tambunan is a tax mafia who was sentenced to 29 years in prison. This phenomenon has led to a situation in which a decrease in tax revenue has occurred.

Based on data from katadata.co.id (Alika, 2019), the level of compliance in reporting SPT (Tax Returns) in 2013 was 62.22\%, then in 2014 it was 62.06\%, while in 2019 it continued to decline to $61.7 \%$. The decrease in the level of tax compliance is the main problem that the Minister of Economy, Sri Mulyani, focuses on. Specifically, Sri Mulyani conveyed regarding the issue of tax compliance that the taxpayers, especially people with high incomes, have low levels of compliance and are an acute problem that has not been resolved (Thomas, 2020). If we trace further the impact that occurs due to distrust which leads to non-compliance with public taxes, of course, state income will also decrease. Taxes are one of the components of the APBN with the largest contribution (Maulida, 2018), so it can be said that the APBN is experiencing a crisis and will have an impact on the stability of the people's economy in Indonesia. As in several years after this case, the state budget is in an income crisis.

Then, researchers found news and data that the APBN deficit was increasing every year, even after the tax amnesty program was implemented and had not yet been able to reach the target. Increasingly, the APBN deficit has become increasingly insurmountable because Jokowi is focused on infrastructure development and is not balanced with state revenues in terms of taxes. Of course, Jokowi's deliberate neglect of the APBN deficit will be very detrimental to the people because one of the functions and objectives of the APBN is to achieve people's welfare, such as providing job opportunities. If it is investigated further regarding the functions of the State Budget, it can be assumed that the Jokowi administration has made several deviations from the functions of the APBN, especially in relation to the people.

Based on Law no. 17 of 2013 concerning State Finance (berkas.dp.go.id), mentioned and explained several functions of the APBN, including the functions of authority, planning, supervision, allocation, distribution, and stabilization. In the function of authority, the state budget becomes the foundation for regulating income and expenditure, just as how most of the tax money from the people is allocated for the benefit of the people as well. So in this function there is a power relationship between the state executive and legislature and the people in terms of the use of tax money.

Then in the supervisory function, it is explained related to democratization in which the people also supervise and assess whether the state uses the APBN for the purposes that are right on target or not, achieving good governance measures or not. One of the benchmarks referred to as good governance is the transparency of the allocation of APBN funds in various social, economic and political activities. Then the question is whether the Indonesian government has achieved the measure of good governance using APBN funds for targeted purposes or not. 
Based on further news data, researchers found that tens of billions of APBN funds entered the personal accounts of officials at five state institutions and the BPK found problems with the use of APBN funds. These problems are related to waste, non-compliance of budget management with laws, and ineffective use of the budget, up to Rp. 10.35 trillion. In addition, the state budget policy regarding distribution must also pay attention to justice for all regions and the people of Indonesia. When viewed from Jokowi's ambition to use APBN funds to increase infrastructure development, the infrastructure problem in Indonesia should be resolved and also distributed evenly to all parts of Indonesia.

However, in reality, the findings of the researchers' data indicate that the infrastructure in Indonesia is still lagging behind. There are still many areas in Indonesia that do not have electricity, schools are not evenly distributed, and so on. Moreover, Jokowi's program to build toll roads cannot be felt by all people, only those who have access can experience the benefits. Jokowi's main priority in infrastructure development is not quite right. The reality of infrastructure problems in Indonesia is still at a basic stage, namely the problem of education and even the problem of electricity. Some areas in Indonesia are still not facilitated by schools and have not had electricity. Instead of overcoming these problems, Jokowi focuses on issues that are not the collective urgency of the Indonesian people, namely toll roads.

In the context of the application of taxes in Indonesia that has been described previously, the state exercises its power to deviate from the established tax system. The state does not carry out a structural function of tax money management so that it has an impact on the fate of the people who are ultimately disadvantaged. Foucaultexplains that power relations run throughout society. Governmentality as a form of power relation also states that there are procedures and rules that lead to hegemonic submission (Foucault, 1991). Based on the way the state works in managing tax money in the APBN, the state does not side with the small people but on the side that benefits the country through economic and political investment. This partiality is the power relation of the state to run, because in essence, power is also synonymous with one-sided gain from a certain group (Martin, 1995).

Based on Foucault's (1978) explanation regarding Governmentality, the phenomenon above is included in sovereign (sovereignty) power, because of the legitimacy of legal validity which regulates the people's obligation to pay taxes, but instead runs repressively because the people are injured victims(Foucault, 1978). In this case, the people were not given information regarding the transparency of the allocation and management of money that the people paid to the state. In the context of the ongoing power relations, the state acts as the executor of political power as well as the perpetrator who cheats and violates the procedural function of the State Budget which comes from public money.

If we look at how the state apparatus works, this phenomenon also relates to Althusser's (2014) RSA (Repressive State Apparatus) theory, which explains that society is in a system and structure of state power that tends to be repressive. The state apparatus in this context is the law administratively which in fact can harm the people. Starting from the state elite who did not deviate, then there was people's distrust of the state elite. In the end, the state did not see this as the main problem, the state remained on the side that benefited the state in the management of the State Budget. The little people are ignored and are even disadvantaged.

Based on the previous explanation, the researcher sees that there is an unbalanced discourse of power relations between the state and the people. The people will always be in a 
repressive state power system and the state uses its political power to submit hegemonically and takes sides that are detrimental to the people structurally and economically. Governmentality always runs under state control and places the people as objects which in the end do not have room to take action (Foucault, 1988).

\section{CONCLUSION}

Based on the formulation of research problems, there are findings of discourse on power relations between the state and the people which refer to Foucault's concept of Governmentality power relations and use Norman Fairclough's Critical Discourse Analysis method. The analysis is divided into two, namely textual lyric analysis. The discourse on power relations of Governmentality is divided into five thematic based on sectoral areas in the country, namely governmentality in the leadership of a democratic state, Governmentality in the Indonesian education system, application of governmentality through the constitution of the ITE Law, governmentality towards the people. agricultural laborers through Agrarian Reform, and the application of governmentality through the management of people's tax money.

In the end, the researchers concluded that the application of governmentality is a discourse of power relations between the state and the people that runs unbalanced. The people will always be in a repressive state power system and the state uses its political power to submit hegemonically and takes sides that harm the people structurally and economically through ISA (Ideological State Apparatus) and RSA (Repressive State Apparatus). Governmentality always runs under the control of the state and places the people as objects who in the end do not have room to take action.

\section{DAFTAR PUSTAKA}

Alika, R. (2019). Pertumbuha Penerimaan Pajak Turun, Ada Potensi Tak Capai Target 2019. Katadata.Co.Id. https://katadata.co.id/sortatobing/finansial/5e9a5513b204d/pertumbuhanpenerimaan-pajak-turun-ada-potensi-tak-capai-target-2019

Althusser, L. (2014). On The Reproduction Of Capitalism: Ideology And Ideological State Apparatuses. Verso.

Badara, A. (2012). Analisis Wacana: Teori, Metode, dan Penerapannya Pada Wacana Media. Prenada Media Group.

Blommaert, J. (2006). Language ideology. Encylopedia of Language and Linguistics, 6, 510522.

Foucault, M. (1978). The Birth of Biopolitics: Lectures at the College de France. Palgrave MacMillan.

Foucault, M. (1988). The Ethic of Care for the Self as a Practice of Freedom (J. Bernauer \& D. Rasmussen (eds.); The Final). Mass: MIT-Press.

Foucault, M. (1991). The Foucault Effect: Studies in Governmentality. University of Chicago Press.

Foucault, M. (2002). Power / Knowledge: Wacana Kuasa / Pengetahuan. Bentang.

Freire, P. (1985). Pendidikan Kaum Tertindas. LP3S.

H57. (2020). Ironi Kebijakan Reforma Agraria Jokowi. Pinterpolitik.Com. https://www.pinterpolitik.com/ironi-kebijakan-reforma-agraria-jokowi/

Hidayat, R. (2016). Ketika Pemerintah Makin Digdaya Memblokir Situs. Tirto.Id. 
https://tirto.id/ketika-pemerintah-makin-digdaya-memblokir-situs-b5tq

Ida, R. (2018). Metode Penelitian Studi Media Dan Kajian Budaya (Cetakan ke). PRENADAMEDIA GROUP.

Imbeau, L. M. (2007). Chapter 8: Leviathan or Geryon? Power Abuse in Democratic Societies. In A. Marciano \& J.-M. Josselin (Eds.), Democracy, Freedom and Coercion. A Law and Economics Approach. https://doi.org/https://doi.org/10.4337/9781847207104

Martin, R. (1995). Sosiologi Kekuasaan. Rajawali Press.

Maulida, R. (2018). Apa Fungsi APBN \& Peran Pajak di Dalamnya? Online-Pajak.Com. https://www.online-pajak.com/tentang-pajak/fungsi-apbn

Mudhoffir, A. M. (2011). Governmentality dan Pemberdayaan dalam Advokasi Lingkungan: Kasus Lumpur Lapindo. $\quad$ Masyarakat, https://doi.org/https://doi.org/10.7454/mjs.v16i1.4877

Mustain. (2017). Petani vs Negara: Gerakan Sosial Petani Melawan Hegemoni Negara. ArRuzz Media.

Nathaniel, F. (2019). Kontroversi Tiga Menteri Baru Jokowi: Terawan, Tirto, \& Zainudin. Tirto.Id. https://tirto.id/kontroversi-tiga-menteri-baru-jokowi-terawan-tito-zainudin-ekir

Petras, J., \& Veltmeyer, H. (2014). Extractive Imperialism in the Americas Capitalism's New Frontier. Brill.

Prastiwi, W. (2017). Kritik Sosial dalam Lirik - Lirik Lagu Iwan Fals yang Tidak Dirilis: Analisis Sosiologi Sastra. Perpustakaan Pusat Universitas Gajah Mada.

Putra, M. . (2016). Lima Musisi Indonesia yang Bernapaskan Sosial Politik. CNN Indonesia. https:/www.cnnindonesia.com/hiburan/20160927143236-227-161462/lima-musisiindonesia-yang-bernapaskan-sosial-politik

Rahardjo, M. (2011). Bahasa Sebagai Alat Komunikasi Publik dan Pembangunan Wacana. Universitas Islam Negeri (UIN) Malang.

Robinson, R. (1986). The Rise of Capital in Indonesia. Allen and Unwin Press.

Rosser, A., \& Fahmi, M. (2018). The political economy of teacher management reform in Indonesia. International Journal of Educational Development, 61(2018), 72-81. https://doi.org/http://dx.doi.org/10.1016/j.ijedudev.2017.12.005

Salahudin, A. (2019). Populisme, Bunglon Politik dan PR Jokowi-Ma'ruf. Mediaindonesia.Com.

Sangadji, A. (2018). Ekonomi Politik Monopoli Penguasaan Tanah, Kelas-Kelas Petani dan Reforma Agraria (Bagian-1). Indoprogress.Com. https://indoprogress.com/2018/08/ekonomi-politik-monopoli-penguasaan-tanah-kelas-kelaspetani-dan-reforma-agraria-bagian-1/

Strinati, D. (2010). Popular Culture: Pengantar Menuju Teori Budaya Populer. Ar-Ruzz Media Group.

Thomas, V. (2020). Di Balik Kegusaran Sri Mulyani Soal Orang Kaya Tak Taat Pajak. Tirto.Id. https://tirto.id/di-balik-kegusaran-sri-mulyani-soal-orang-kaya-tak-taat-pajak-exul 